Research, part of a Special Feature on Effects of Roads and Traffic on Wildlife Populations and Landscape Function

\title{
Cost-Benefit Analyses of Mitigation Measures Aimed at Reducing Collisions with Large Ungulates in the United States and Canada: a Decision Support Tool
}

\author{
$\underline{\text { Marcel P. Huijser }}{ }^{1}, \underline{\text { John W. Duffield }}^{2}, \underline{\text { Anthony P. Clevenger }}^{1}, \underline{\text { Robert J. Ament }}^{1}$, and $\underline{\text { Pat T. McGowen }}^{1}$
}

\begin{abstract}
Wildlife-vehicle collisions, especially with deer (Odocoileus spp.), elk (Cervus elaphus), and moose (Alces alces) are numerous and have shown an increasing trend over the last several decades in the United States and Canada. We calculated the costs associated with the average deer-, elk-, and moose-vehicle collision, including vehicle repair costs, human injuries and fatalities, towing, accident attendance and investigation, monetary value to hunters of the animal killed in the collision, and cost of disposal of the animal carcass. In addition, we reviewed the effectiveness and costs of 13 mitigation measures considered effective in reducing collisions with large ungulates. We conducted cost-benefit analyses over a 75 -year period using discount rates of $1 \%, 3 \%$, and $7 \%$ to identify the threshold values (in 2007 U.S. dollars) above which individual mitigation measures start generating benefits in excess of costs. These threshold values were translated into the number of deer-, elk-, or moose-vehicle collisions that need to occur per kilometer per year for a mitigation measure to start generating economic benefits in excess of costs. In addition, we calculated the costs associated with large ungulate-vehicle collisions on 10 road sections throughout the United States and Canada and compared these to the threshold values. Finally, we conducted a more detailed cost analysis for one of these road sections to illustrate that even though the average costs for large ungulate-vehicle collisions per kilometer per year may not meet the thresholds of many of the mitigation measures, specific locations on a road section can still exceed thresholds. We believe the cost-benefit model presented in this paper can be a valuable decision support tool for determining mitigation measures to reduce ungulate-vehicle collisions.
\end{abstract}

Key Words: animal-vehicle collisions; cost-benefit analysis; deer; economic; effectiveness; elk; human injuries andfatalities; mitigation measures; moose; roadkill; ungulate; vehicle repair cost; wildlife-vehicle collision

\section{INTRODUCTION}

Wildlife-vehicle collisions affect human safety, property and wildlife. The total number of large mammal-vehicle collisions has been estimated at one to two million in the United States and at 45 000 in Canada annually (Conover et al. 1995, Tardif and Associates Inc. 2003, Huijser et al. 2007b). These numbers have increased even further over the last decade (Tardif and Associates Inc. 2003, Huijser et al. 2007b). In the United States, these collisions were estimated to cause 211 human fatalities, 29000 human injuries and over one billion US dollars in property damage annually (Conover et al. 1995). In most cases, the animals die immediately or shortly after the collision (Allen and McCullough 1976). In some cases, it is not just the individual animals that suffer. Road mortality may also affect some species on the population level (e. g., van der Zee et al. 1992, Huijser and Bergers 2000), and some species may even be faced with a serious reduction in population survival probability as a result of road mortality, habitat fragmentation, and other negative effects associated with roads and traffic (Proctor 2003, Huijser et al. 2007b). In addition, some species also represent a monetary value that is lost once an individual animal dies (Romin and Bissonette 1996, Conover 1997). 
Although this paper focuses on collisions with large ungulates, this group is not necessarily the most abundant or the most important species group hit by vehicles. Species groups most often reported in roadkill surveys include amphibians, reptiles, birds, and mammals (Seibert and Conover 1991, Holsbeek et al. 1999, Ament et al. 2008, Gryz and Krauze 2008). The relative proportion at which these species groups are recorded in roadkill surveys in different countries varies substantially: $1.8 \%-$ $70.8 \%$ for amphibians, $<0.1 \%-7.4 \%$ for reptiles, $3.1 \%-52 \%$ for birds, and $4.2 \%-87.2 \%$ for mammals (Seibert and Conover 1991, Kratky 1995, Holsbeek et al. 1999, Gryz and Krauze 2008, Hobday and Minstrell 2008). A review by Seiler (2003) showed that the numbers of road-killed birds and mammals in various countries are typically estimated at multiple millions per year. Surveys that include invertebrates indicate that mortality rates of invertebrates due to collision with vehicles are far higher than for vertebrates: in one study, $86 \%$ of all observations related to invertebrates (Seibert and Conover 1991). However, mitigation measures are most often implemented for species that are large enough to pose a threat to human safety or species whose population survival probability is severely affected by roads and traffic (e.g., Mansergh and Scotts 1989, van der Ree et al. 2009). In addition, data collected by law enforcement agencies (crash data) and transportation agencies (carcass data) are typically limited to large mammals (Huijser et al. 2007a).

Over 40 types of mitigation measures aimed at reducing collisions with large ungulates have been described (see reviews in Hedlund et al. 2004, Knapp et al. 2004, Huijser et al. 2007b). Examples include warning signs that alert drivers to potential animal crossings, wildlife warning reflectors or mirrors (e.g., Reeve and Anderson 1993, Ujvári et al. 1998), wildlife fences (Clevenger et al. 2001), and animal detection systems (Huijser et al. 2006b). However, the effectiveness and costs of these mitigation measures vary greatly. When the effectiveness is evaluated in relation to the costs for the mitigation measure, important insight is obtained regarding which mitigation measures may be preferred, at least from a monetary perspective. Nonetheless, very few cost-benefit analyses exist (but see, e.g., Reed et al. 1982), and although this may seem surprising, wildlife-vehicle collisions, at least until recently, are not always included in safety analyses by transportation agencies, let alone in cost-benefit analyses (Knapp and Witte 2006).
Transportation agencies in the United States and Canada typically do not have access to basic cost and benefit data, and do not have comprehensive analysis tools available to them (Knapp and Witte 2006). Over the last decades, the dominant practice for transportation agencies has been to install wildlife warning signs when (variable) thresholds were reached for ungulate-vehicle collisions (Knapp and Witte 2006). However, the implementation of these signs has typically not been based on a cost-benefit analysis. In addition, such thresholds typically relate to relatively short road sections (e.g., 0.25 or 0.50 miles $(402 \mathrm{~m}$ or $805 \mathrm{~m})$ ), whereas ungulate-vehicle collisions typically need to be analyzed and mitigated at a larger spatial scale. Finally, anecdotal information and crash and carcass data summaries are also used to justify more substantial mitigation measures such as wildlife fencing combined with safe wildlife crossing opportunities, but decisions to implement such mitigation measures are rarely based on costbenefit analyses (Knapp and Witte 2006; Pat Basting, Montana Department of Transportation, pers. comm.; Doug Herbrand, Ontario Ministry of Transportation, pers. comm.).

In this paper, we compare the monetary costs and benefits of a range of mitigation measures aimed at reducing collisions with large ungulates. In the United States, most of the wildlife-vehicle collisions reported by agencies involve deer (Odocoileus spp.). In addition, the vast majority of all animal-vehicle collisions that result in human injury $(86.9 \%)$ or human fatality $(77 \%)$ involve deer as well (Conn et al. 2004, Williams and Wells 2005). The numbers vary between regions: in California, deer amount to $54.4 \%$ of the reported animalvehicle collisions, in Maine $81.2 \%$ (Huijser et al. 2007b). In certain areas, e.g., Maine, collisions with moose (Alces alces) are relatively numerous (15.1\%) (Huijser et al. 2007b). Of all the claims submitted to a major auto insurance company in the United States (national market share about 17.5\%) in 2006-2007 for vehicle repair as a result of a collision with deer, elk (Cervus elaphus), or moose, $99.2 \%$ related to deer, $0.5 \%$ to elk, and $0.3 \%$ to moose ( $n$ is approximately 180000 ) (Dick Luedke, State Farm Insurance, pers. comm.). In British Columbia, Canada, $85.6 \%$ of all reported animals killed by traffic were deer $(78.6 \%)$ or moose $(7.0 \%)$ (Sielecki 2004). In the Ottawa-Carleton area, Canada, $93.1 \%$ of all reported animal-vehicle collisions involved deer $(92.2 \%)$ or moose $(0.9 \%)$ (Tardif and Associates Inc. 2003). For this paper, 
we conducted separate analyses for the costs and benefits of mitigation measures aimed at reducing collisions with deer (white-tailed deer $(O$. virginianus) and mule deer (O. hemionus) combined), elk, and moose.

Our cost-benefit analyses do not include passiveuse costs. Passive or nonuse values are generally based on existence or bequest motives and include values in addition to those that arise directly due to the collision (Krutilla 1967, Daily et al. 1997). In this context, passive values could include the value individuals (even those who perhaps never drive the road section of interest) place on having viable populations of certain species and well-functioning ecosystems as a result of the reduced road mortality and a certain amount of connectivity for wildlife associated with a mitigation measure. Connectivity across roads for wildlife is also in the interest of human safety as animals are more likely to break through a barrier (e.g., wildlife fencing) if safe crossing opportunities are not provided or if they are too few, too small, or too far apart. Even if wildlife fencing is combined with safe crossing opportunities for wildlife, animals may still end up in between the fences, caught in the transportation corridor, and these animals pose a risk to human safety. For these reasons, it is considered good practice to accompany absolute barriers, such as wildlife fencing, with safe crossing opportunities for wildlife and escape opportunities for animals that end up in between the fences. For this paper, we addressed the importance of safe crossing opportunities for wildlife by reviewing the individual mitigation measures for their potential barrier effect on the movements of large ungulates.

The results of our economic analyses apply to the United States and Canada, but not necessarily to other countries or regions, because we used species characteristics and economic data from these two countries. Furthermore, we realize that the results of the analyses are directly dependent on the parameters included in the analyses and the assumptions and estimates required to conduct the analyses. Nonetheless, the results of the costbenefit analyses allow for much needed direction for transportation agencies and natural resource management agencies in the implementation and further research and development of mitigation measures aimed at reducing collisions with large ungulates.

\section{METHODS}

\section{Cost-Benefit Analyses}

We estimated the effectiveness of 13 types of mitigation measures for reducing collisions with large ungulates such as deer, elk, and moose, and whether these mitigation measures still allow animals to cross the road (Table 1). Of the 13 measures listed, only wildlife fencing is an absolute barrier for large ungulates. In addition, we estimated the costs (in 2007 US\$) of these mitigation measures per year over a 75-year period (Appendix 1, Table $1)$. The costs included design, construction or implementation, maintenance, and removal efforts. The 75-year period is equal to the longest lifespan of the mitigation measures reviewed (i.e., underpasses and overpasses). In the 75 th year, no new investments were projected (only maintenance and removal costs) for the following mitigation measures: wildlife fence alone (Fig. 1); wildlife fence, gap, and crosswalk; wildlife fence, underpasses, and jump-outs (Figs. 2 and 3); wildlife fence, and under- and overpasses (Fig. 4); wildlife fence and animal detection systems (Fig. 5); elevated roadway; and road tunnel. Jump-outs are earthen ramps that allow animals that are trapped in between the fences in the road corridor to walk up to the top of the fence and jump down to safety. Well designed jump-outs are low enough to allow animals to jump to safety, and high enough to discourage them from jumping up into the road corridor.

We also estimated the benefits generated by the 13 mitigation measures. The benefits are a combination of the effectiveness of the mitigation measures in reducing collisions with large ungulates and the costs associated with the average collision. The cost of a collision with a large ungulate typically increases with the size and weight of the species. For this analysis, we estimated the costs for the average collision with a deer, an elk, or a moose (Appendix 2, Table 2). Some mitigation measures take considerable planning and installation time. For such measures, we did not project any benefits in the first year of the cost-benefit analyses. This delay in the start of the benefits applied to all mitigation measures, except seasonal signs, vegetation removal, population culling, relocation, and anti-fertility treatment.

For our cost-benefit analyses, all costs and benefits are in real terms (i.e., constant 2007 US\$). 
Table 1. The estimated effectiveness, present value costs (in 2007 US\$, 3\% discount rate), and costs per percent reduction of mitigation measures aimed at reducing collisions with large ungulates over a 75-year time period. The measures are ordered based on their estimated effectiveness. If a measure is estimated to be $86 \%$ effective, it means that ungulate-vehicle collisions are estimated to reduce by $86 \%$ as a result of the implementation of that mitigation measure (e.g., a reduction from 100 collisions to 14 collisions).

\begin{tabular}{|c|c|c|c|c|c|}
\hline $\begin{array}{l}\text { Mitigation } \\
\text { measure }\end{array}$ & Effectiveness & $\begin{array}{l}\text { Crossing } \\
\text { opportunity? }\end{array}$ & Source & $\begin{array}{l}\text { Present value } \\
\text { costs (US\$) }\end{array}$ & $\begin{array}{l}\text { Costs per } \\
\text { percent } \\
\text { reduction } \\
\text { (US\$) }\end{array}$ \\
\hline $\begin{array}{l}\text { Seasonal wildlife warning } \\
\text { sign }\end{array}$ & $26 \%$ & Yes & $\begin{array}{l}\text { Sullivan et al. (2004): 51\%; Rogers (2004): } \\
0 \%\end{array}$ & $\$ 3728$ & $\$ 143$ \\
\hline Vegetation removal & $38 \%$ & Yes & $\begin{array}{l}\text { Jaren et al. (1991): 56\%; Lavsund and } \\
\text { Sandegren (1991): } 20 \%\end{array}$ & $\$ 16272$ & $\$ 428$ \\
\hline Fence, gap, crosswalk & $40 \%$ & Yes & Lehnert and Bissonette (1997): 42\%, 37\% & $\$ 300468$ & $\$ 7512$ \\
\hline Population culling & $50 \%$ & Yes & Review in Huijser et al. (2007a) & $\$ 94809$ & $\$ 1896$ \\
\hline Relocation & $50 \%$ & Yes & Review in Huijser et al. (2007a) & $\$ 391870$ & $\$ 7837$ \\
\hline Anti-fertility treatment & $50 \%$ & Yes & Review in Huijser et al. (2007a) & $\$ 2183207$ & $\$ 43664$ \\
\hline Fence (incl. dig barrier) & $86 \%$ & No & $\begin{array}{l}\text { Reed et al. (1982) 79\%; Ward (1982): 90\% } \\
\text { Woods (1990): 94\%-97\%; Clevenger et al. } \\
\text { (2001): 80\%; Dodd et al. (2007): } 87 \%\end{array}$ & $\$ 187246$ & $\$ 2177$ \\
\hline $\begin{array}{l}\text { Fence, underpass, jump- } \\
\text { out }\end{array}$ & $86 \%$ & Yes & $\begin{array}{l}\text { Reed et al. (1982) 79\%; Ward (1982): } 90 \% \\
\text { Woods (1990): 94\%-97\%; Clevenger et al. } \\
\text { (2001): 80\%; Dodd et al. (2007): } 87 \%\end{array}$ & $\$ 538273$ & $\$ 6259$ \\
\hline $\begin{array}{l}\text { Fence, under- and } \\
\text { overpass, } \\
\text { jump-out }\end{array}$ & $86 \%$ & Yes & $\begin{array}{l}\text { Reed et al. (1982) 79\%; Ward (1982): 90\% } \\
\text { Woods (1990): 94\%-97\%; Clevenger et al. } \\
\text { (2001): 80\%; Dodd et al. (2007): } 87 \%\end{array}$ & $\$ 719667$ & $\$ 8368$ \\
\hline $\begin{array}{l}\text { Animal detection system } \\
\text { (ADS) }\end{array}$ & $87 \%$ & Yes & $\begin{array}{l}\text { Mosler-Berger and Romer (2003): } 82 \% \text {; Dodd } \\
\text { and Gagnon (2008): } 91 \%\end{array}$ & $\$ 1099370$ & $\$ 12636$ \\
\hline Fence, gap, ADS & $87 \%$ & Yes & $\begin{array}{l}\text { Mosler-Berger and Romer (2003): 82\%; Dodd } \\
\text { and Gagnon (2008): } 91 \%\end{array}$ & $\$ 836113$ & $\$ 9610$ \\
\hline Elevated roadway & $100 \%$ & Yes & Review in Huijser et al. (2007a) & $\$ 92355498$ & $\$ 923555$ \\
\hline Road tunnel & $100 \%$ & Yes & Review in Huijser et al. (2007a) & $\$ 147954696$ & $\$ 1479547$ \\
\hline
\end{tabular}

Accordingly, as we excluded inflation effects in our benefit and cost streams over time, we also used real (as opposed to nominal) discount rates. Presenting the analysis in nominal terms with inflation included in future values and an inflation component in the discount term would be mathematically equivalent. In order to correctly compare benefit and cost elements, which are distributed asymmetrically over time, we computed present discounted values and amortized these into equivalent annual terms. The typical pattern for the mitigation measures we examined is that costs are largely construction oriented in the present (e.g., an investment in a fence with an underpass in the first year of a 75-year period) whereas benefits are distributed more uniformly over the life of the project (i.e., a certain 


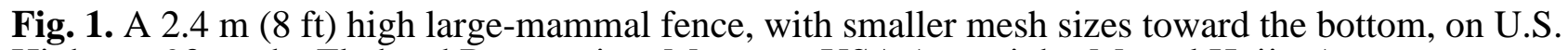
Highway 93 on the Flathead Reservation, Montana, USA (copyright: Marcel Huijser).

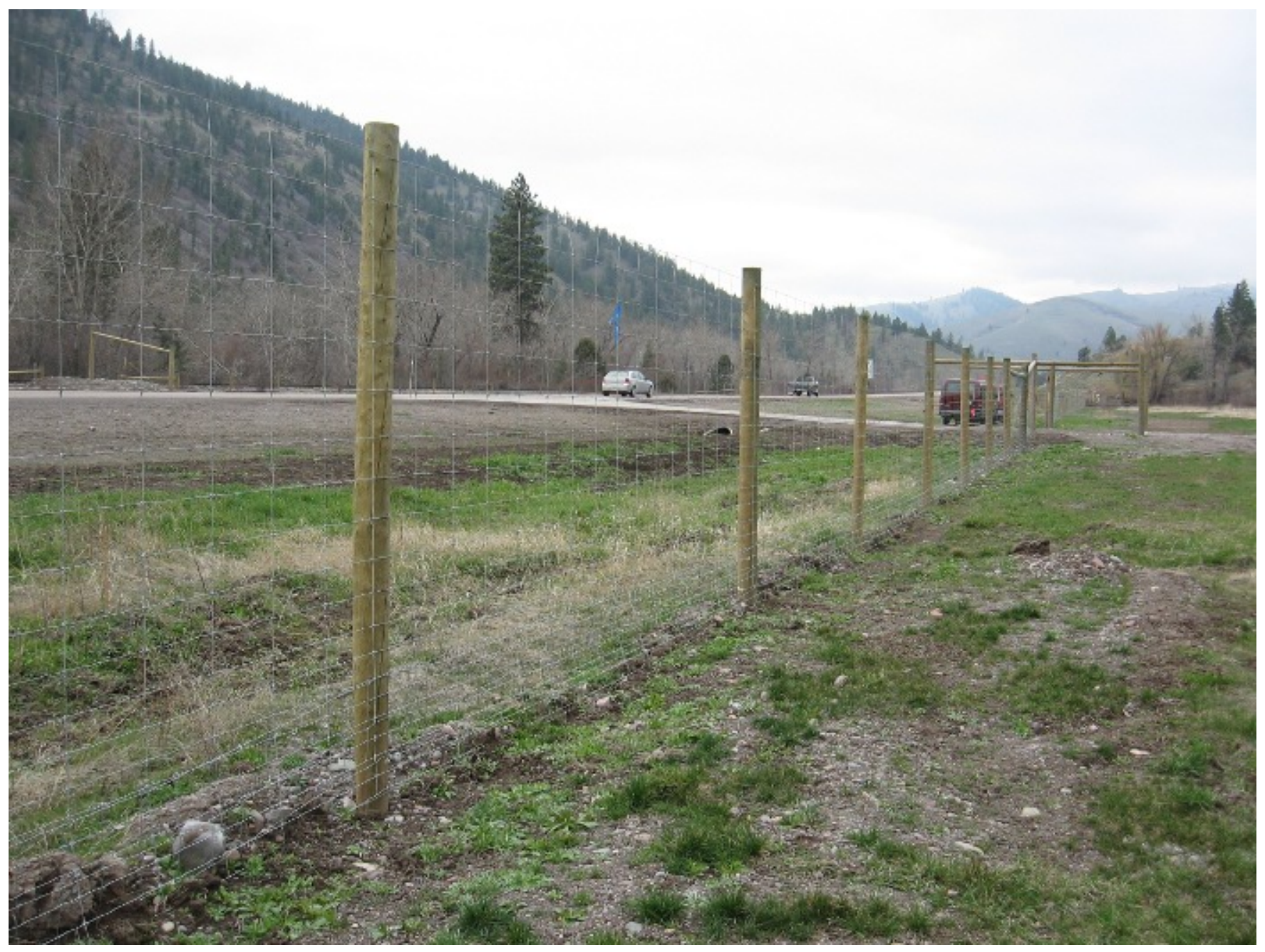

reduction in collisions and associated costs each year). In this situation, the cost-benefit analysis is sensitive to the discount rate chosen. The discount rate simply corrects for the time value of money. For example, if an individual can earn a fixed $3 \%$ interest on savings or investments, then a dollar today is worth US\$1.03 one year from now. Conversely, a dollar promised to be paid one year from now is worth only (discounted to) about US\$0.97 today.

Following the guidance provided in the U.S. Office of Management and Budget (OMB) Circular A-94
(U.S. OMB 1992) and other federal guidelines (U. S. Environmental Protection Agency 2000), we conducted the analyses for real discount rates of $7 \%$, $3 \%$, and $1 \%$. The $7 \%$ rate is required by OMB for federal benefit-cost analyses and is based on a shadow price of capital theory; specifically (at least in 1992) $7 \%$ is OMB's estimate of the real after-tax return on investment in the private sector (essentially the opportunity cost of instead investing in public projects). A more widely accepted discount parameter for at least intra-generational accounting is choosing a social discount rate based on the rate at which individuals translate 
Fig. 2. A large-mammal underpass (7-8 m (23-26.2 ft) wide, 4-5 m (13.1-16.4 ft) high) along U.S. Highway 93 on the Flathead Reservation, Montana, USA (copyright: Marcel Huijser).

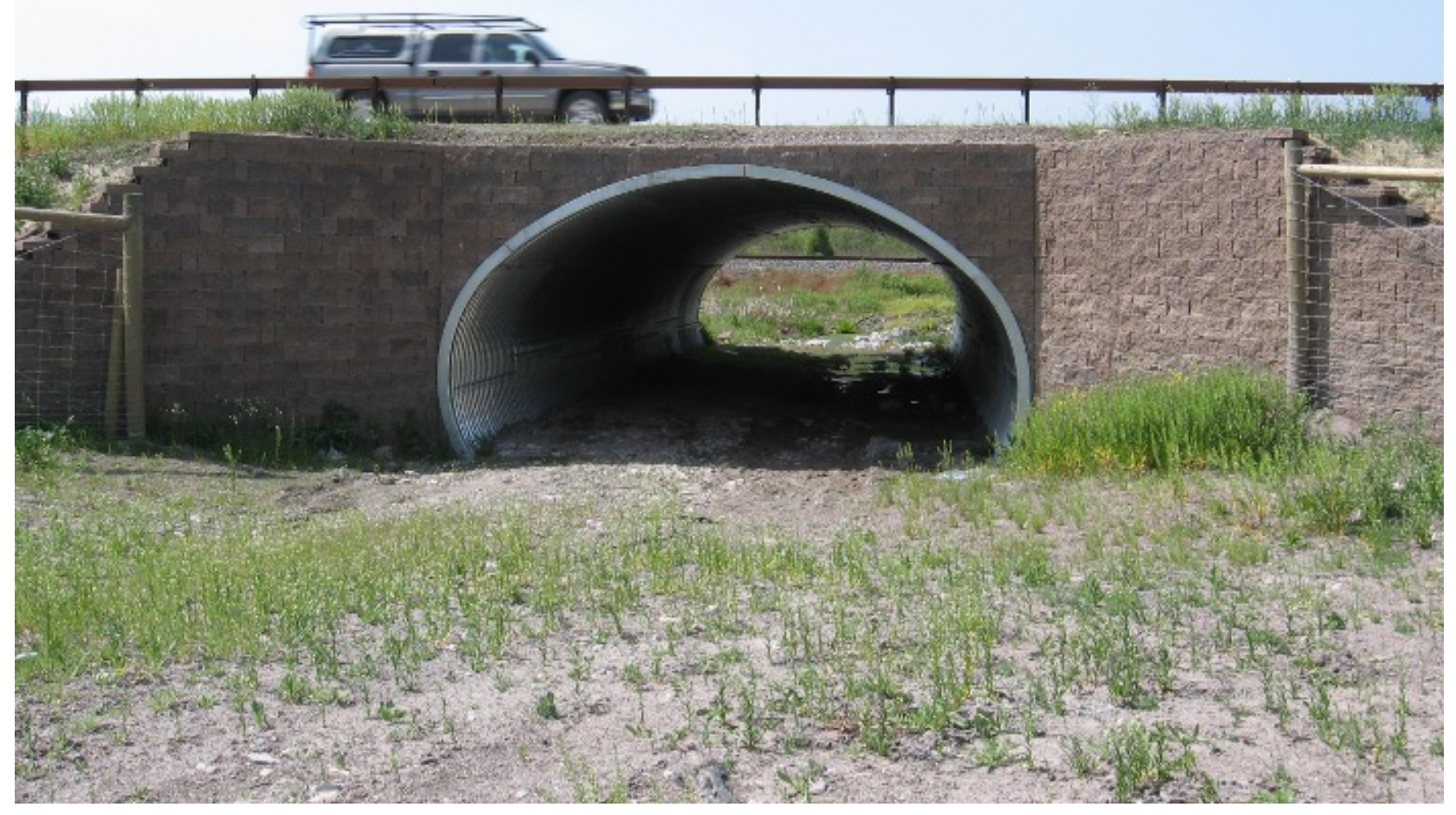

consumption through time with reasonable certainty (e.g., a consumption rate of interest theory). For this, historical returns on safe assets such as U.S. Treasury securities are used (post-tax and corrected for inflation), with empirical estimates for rates in the $1 \%$ to $3 \%$ range (U.S. Environmental Protection Agency 2000). For inter-generational discounting (for which a project with a lifespan of 75 years would obviously qualify) other theories based in part on ethical considerations that explicitly trade-off the well-being of current and future generations come into play, and rates of $0.5 \%$ to $3 \%$ are plausible. As an example from the economics literature, a recent survey of several thousand economists on the issue of an appropriate discount rate for the problem of global warming indicated a wide-range of opinions on the appropriate rate, rates declining over the time period of the analysis from about $4 \%$ to $0 \%$ for the very long term, and a long-term average rate of $1.75 \%$ in real terms (Weitzman 2001). Sumaila and Walters (2005) provide an alternative framework for intergenerational discounting and an overview of the recent literature on this issue.

After estimating the costs for each mitigation measure, and after correcting for the discount rate, 
Fig. 3. A short section of perpendicular fence to guide animals on top of a jump-out along a $2.4 \mathrm{~m}(8 \mathrm{ft})$ high fence along U.S. Highway 93 on the Flathead Reservation, Montana, USA (copyright: Marcel Huijser).

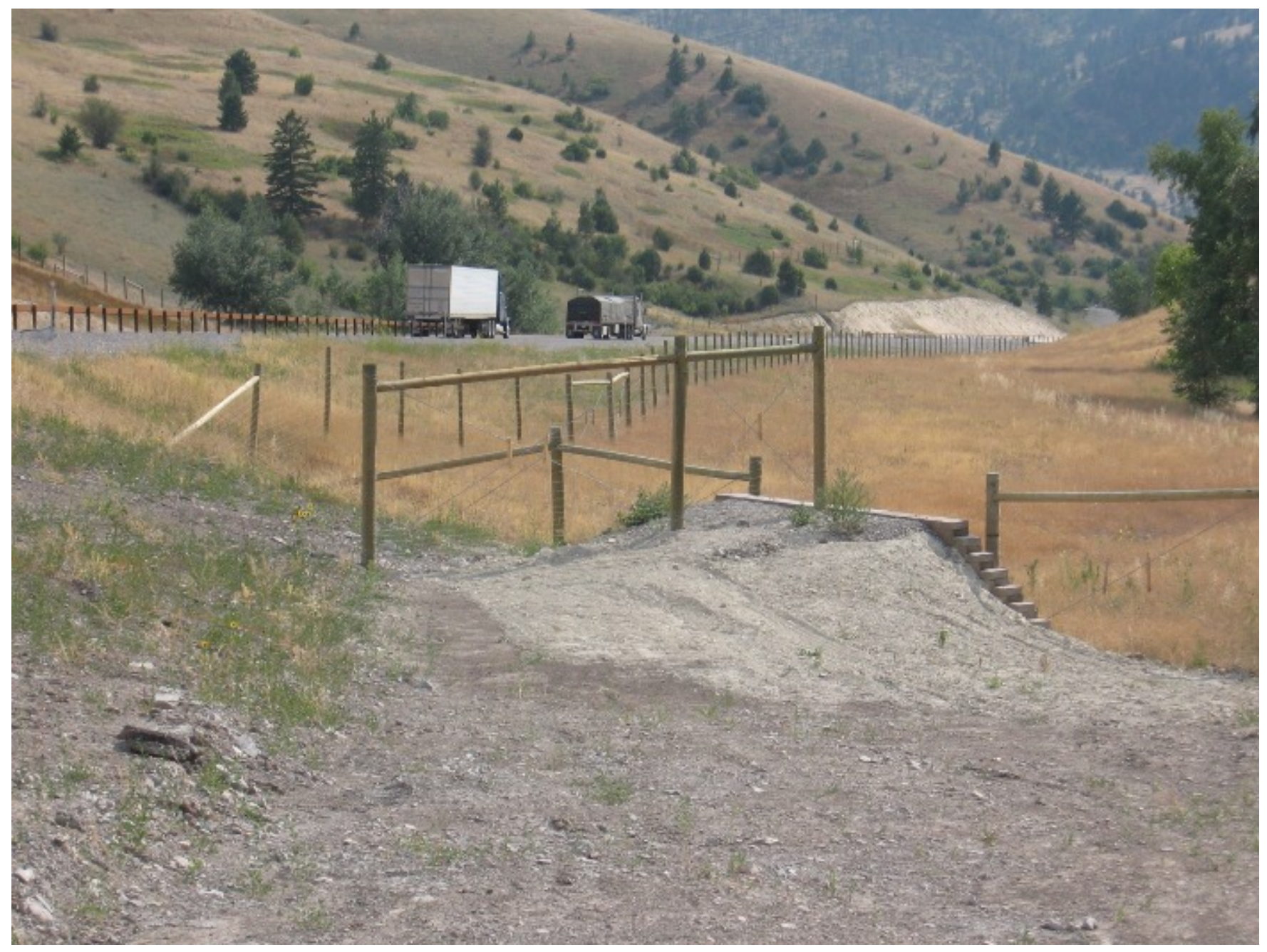

we calculated how much benefit (in 2007 US\$) each mitigation measure needs to generate over a 75-year period in order to break even and have the benefits exceed the costs (threshold values). Equation 1 shows our methods for estimating costs:

$$
A_{j}=\left[\sum_{t=1}^{n} \frac{c_{t j}}{(1+d)^{t}}\right]\left[\frac{(1+d)^{n} \cdot d}{(1+d)^{n}-1}\right]
$$

The first term is simply the present value of costs over the period $t$ equals 1 to $n$ with discount rate $d$ and annual costs $\left(c_{t j}\right)$ in year $t$ for mitigation measure $j$. The second term is an amortization factor (the share that yields the annual equivalent of a fixed 
Fig. 4. Wildlife overpass in Banff National Park, Alberta, Canada (copyright: Marcel Huijser).

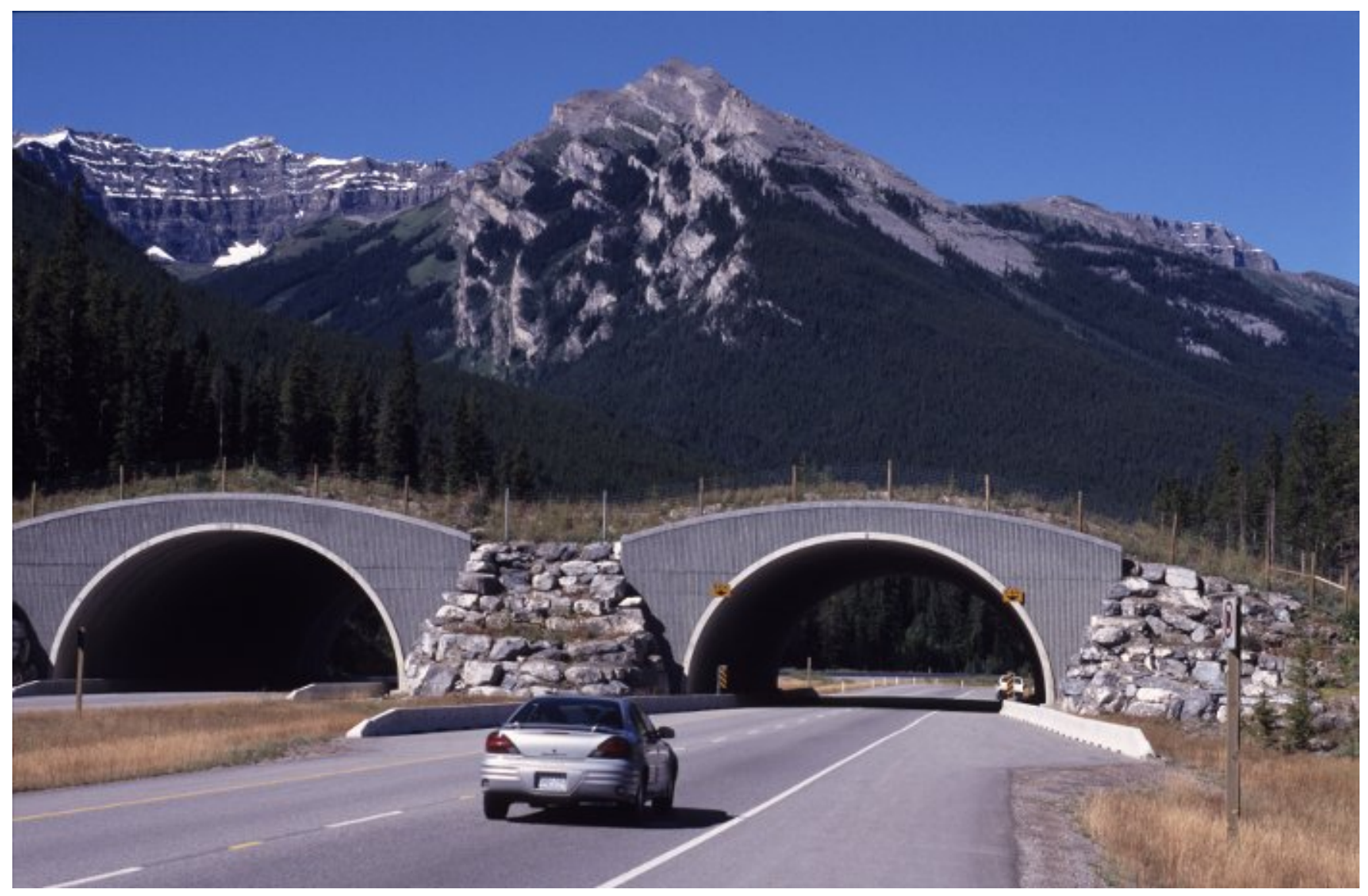

sum over some time period, as in the annual payments on a 30-year mortgage); the product of the two terms equals $A_{j}$, which is the amortized real annual cost over period $n$ for technology $j$. Annual benefits are given by Eq. 2 :

$$
B_{j}=r_{j} k \sum_{i=1}^{m} \alpha_{i} c_{i}+\sum_{i=1}^{m} v_{i j}
$$

Annual benefits are the sum of the reduction in direct collision costs for species $i$ (equals 1 to $m$ ) and any annual nonuse or passive-use values $v_{i j}$ for these species. With respect to direct collision costs, $r_{j}$ is the reduction in wildlife-vehicle collisions from mitigation measure $j$ ( $r$ is a ratio) and $k$ is the initial pre-mitigation level of wildlife-vehicle collisions per kilometer per year for the road section of interest. The term $r k$ accordingly is the reduction in the number of wildlife-vehicle collisions. The average species-weighted average cost per collision is the summation of the share of collisions $\left(\alpha_{i}\right)$ due to species $i$ times species-specific collision costs $c_{i}$. The summed product of the reduction in collisions and the average cost per collision $\left(\alpha_{i} c_{i}\right)$ gives the benefits associated with a given mitigation measure. Setting annual benefits for mitigation measure $j$ equal to annual costs and solving for $k$ yields the breakeven level of pre-mitigation collisions, which we designate $k_{j}^{*}$, above which annual benefits will exceed costs, e.g., net benefits are positive, as shown in Eq. 3: 
Fig. 5. Animal detection system along U.S. Highway 191 in Yellowstone National Park, Montana, USA (copyright: Marcel Huijser).

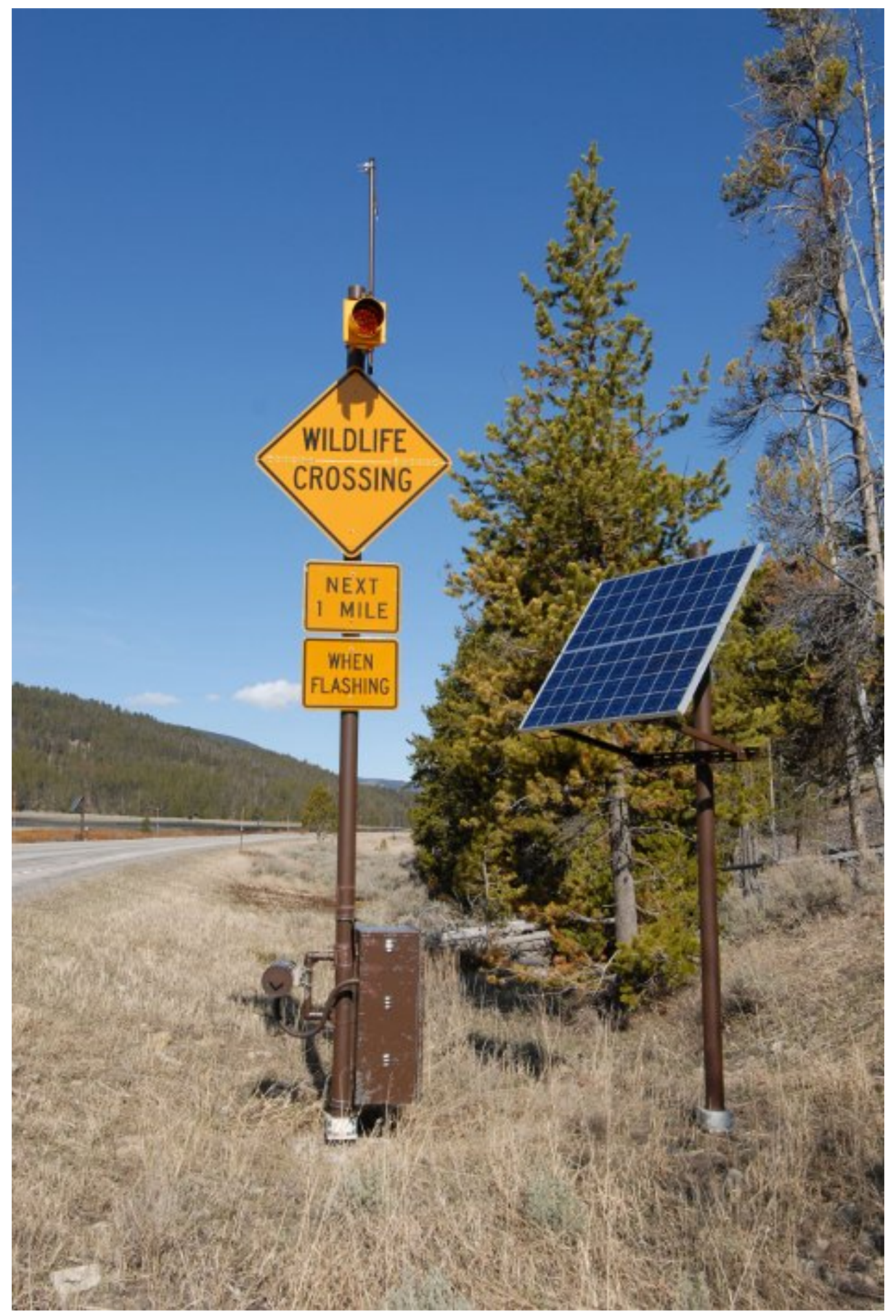


Table 2. Summary of estimated costs (in 2007 US\$) for the average deer-, elk-, and moose-vehicle collision.

\begin{tabular}{|c|c|c|c|}
\hline Description & $\begin{array}{r}\text { Deer } \\
\text { (US\$) }\end{array}$ & $\begin{array}{r}\text { Elk } \\
\text { (US\$) }\end{array}$ & $\begin{array}{c}\text { Moose } \\
\text { (US\$) }\end{array}$ \\
\hline Vehicle repair costs per collision & $\$ 2622$ & $\$ 4550$ & $\$ 5600$ \\
\hline Human injuries per collision & $\$ 2702$ & $\$ 5403$ & $\$ 10807$ \\
\hline Human fatalities per collision & $\$ 1002$ & $\$ 6683$ & $\$ 13366$ \\
\hline Towing, accident attendance, and investigation & $\$ 125$ & $\$ 375$ & $\$ 500$ \\
\hline Hunting value animal per collision & $\$ 116$ & $\$ 397$ & $\$ 387$ \\
\hline Carcass removal and disposal per collision & $\$ 50$ & $\$ 75$ & $\$ 100$ \\
\hline Total & $\$ 6617$ & $\$ 17483$ & $\$ 30760$ \\
\hline
\end{tabular}

$$
k_{j}^{*}=\frac{A_{j}-\sum v_{i j}}{\left(r_{j} \cdot \sum \alpha_{i} \cdot c_{i}\right)}
$$

As one would expect, the number of collisions required is directly proportional to the mitigation measure cost $A$ (the higher the costs, the more collisions needed to justify) and inversely proportional to the benefit (reduction in collisions) achieved by the mitigation measure. To the extent there are annual passive-use benefits $\left(v_{i j}\right)$, these reduce annual costs. For the simplified case of a single species and no passive-use values, the breakeven value is simply (Eq. 4):

$$
k_{j}^{*}=\frac{A_{j}}{r_{j} \cdot c_{i}}
$$

Note that the right-hand term is simply total annual costs of the mitigation measure divided by the benefits (avoided costs) per collision. If one expresses $r_{j}$ in terms of percent reduction, then $A f$ $r_{j}$ is the cost of a $1 \%$ reduction in collisions. It is useful to compute this unit cost (cost per $1 \%$ reduction) in the following section in comparing the costs of different mitigation measures. The next two sections provide a summary of the effectiveness and costs of the mitigation measures, and the costs associated with deer-, elk-, and moose-vehicle collisions.

\section{Effectiveness and Costs of Mitigation Measures}

We reviewed approximately 40 different types of mitigation measures or combinations of mitigation measures that aim to reduce collisions with large animals (deer and larger) (for full review see Huijser et al. 2007b). Based on the available data, 13 of these measures were considered effective in reducing collisions with large animals (effectiveness $>0 \%$ ) (Table 1). For example, if there were 10 reported collisions with large ungulates per kilometer per year on a road section, then the implementation of a combination of wildlife fencing, underpasses, and jump-outs is estimated to reduce these collisions by $86 \%$ to 1.4 reported collisions per kilometer per year (Table 1). If more than one estimate was available for the effectiveness of each of the 13 mitigation measures reviewed, the mean was calculated. As the 
effectiveness of some of the mitigation measures is highly variable or based on only one study, additional studies may lead to an adjustment of these values at a later time. Mitigation measures considered ineffective (effectiveness estimated at 0\% (Huijser et al. 2007b)), lacking effectiveness data, or having insufficient data were excluded from the cost-benefit analyses in this paper.

Each mitigation measure's suitability depends on the species concerned, the specific objectives of a project, and local circumstances. This paper does not discuss the advantages and disadvantages of each mitigation measure, but it is important to be aware that some mitigation measures may only be suited for very specific circumstances. For example, population culling, the relocation of individuals or infertility treatment of individuals may only be practical and effective for relatively small and closed populations (Seagle and Close 1996, Rudolph et al. 2000). Furthermore, such measures are typically applied to deer rather than other species. See Huijser et al. (2007a) for a discussion on other considerations.

The estimated costs for each of the mitigation measures over a 75-year period vary greatly, as did the costs per percent reduction in collisions (Table 1). Appendix 1 provides a rationale for the estimated costs of the individual mitigation measures.

\section{Cost Estimates for Deer-, Elk-, and Moose- Vehicle Collisions}

The justification for the cost estimates for deer-, elk-, and moose-vehicle collisions is in Appendix 2 . The total estimated costs for the average deer-, elk-, and moose-vehicle collision is summarized in Table 2. As we calculated the costs for an average collision, the costs of collisions that result in human injuries or fatalities, in addition to property damage, are higher than this average. Similarly, the costs of collisions that result in property damage only are lower than these average costs. The advantage of using the costs of an average collision is that no assumptions have to be made whether a particular accident (past or future) did or will result in human injuries or fatalities; this is averaged out. Most of the costs are associated with human injuries and fatalities (deer: 56.0\%; elk: 69.1\%; moose: 78.6\%) rather than vehicle repair costs (deer: $39.6 \%$; elk: $26.0 \%$; moose: $18.2 \%$ ). Based on a total estimate of one to two million collisions with large mammals per year in the United States (Huijser et al. 2007b) and the estimate that $99.2 \%$ of all reported wildlifevehicle collisions related to deer, $0.5 \%$ to elk, and $0.3 \%$ to moose (see introduction), the total estimated annual costs associated with ungulatevehicle collisions is estimated at US\$6247 759000 US\$12 495518000 . In Canada, with an estimated 45000 large mammal-vehicle collisions, the estimated annual costs are US\$281 149155 (Tardif and Associates Inc. 2003). Although we acknowledge that there is geographical variation in the body size of deer, elk, and moose, and thus in the costs associated with a collision, the estimates presented in this manuscript are typically based on average values for large geographical areas (e.g., a nation) or the results of several studies in different geographical areas, resulting in estimates for the United States and Canada combined rather than estimates for a particular region.

\section{RESULTS}

\section{Illustration Output Cost-Benefit Model}

Figure 6 shows the threshold values (in 2007 US\$) for a specific mitigation measure: fencing with underpasses and jump-outs. For this specific mitigation measure, there is an initial construction cost in the first year of US\$416 191, with annual maintenance of US\$1500 per year and fence removal and replacement in year 25 and 50 of US\$107 500 and removal less salvage in year 75 of US\$26 500 (all costs in 2007 US\$ per kilometer) (see Appendix 1 for justification). The present value (3\% discount rate) of this mitigation measure is US\$538 273 and annual amortized value per kilometer is US\$18 123. The annual amortized values at $7 \%$ and $1 \%$ are US\$32 457 and US\$12 437 , respectively. These annual costs at the three discount rates are shown as horizontal lines (Fig. 6). The lines representing the costs associated with premitigation collisions with deer, elk, and moose cross the horizontal lines representing the annual amortized values at the break-even points. For $3 \%$ discount rate, the break-even point for deer, elk, and moose is $3.2,1.2$, and 0.7 collisions per kilometer per year, respectively (Fig. 6). If more collisions occur, then implementing fencing with underpasses and jump-outs generates economic benefits in excess of costs. Similarly, if fewer collisions occur then the implementation of this mitigation measure has costs in excess of benefits. 
Fig. 6. The number of deer-, elk-, and moose-vehicle collisions per kilometer per year (dotted lines) needed to reach the threshold values (7\%, 3\%, and 1\% discount rate) (in real 2007 US\$) (solid lines) for fencing with underpasses.

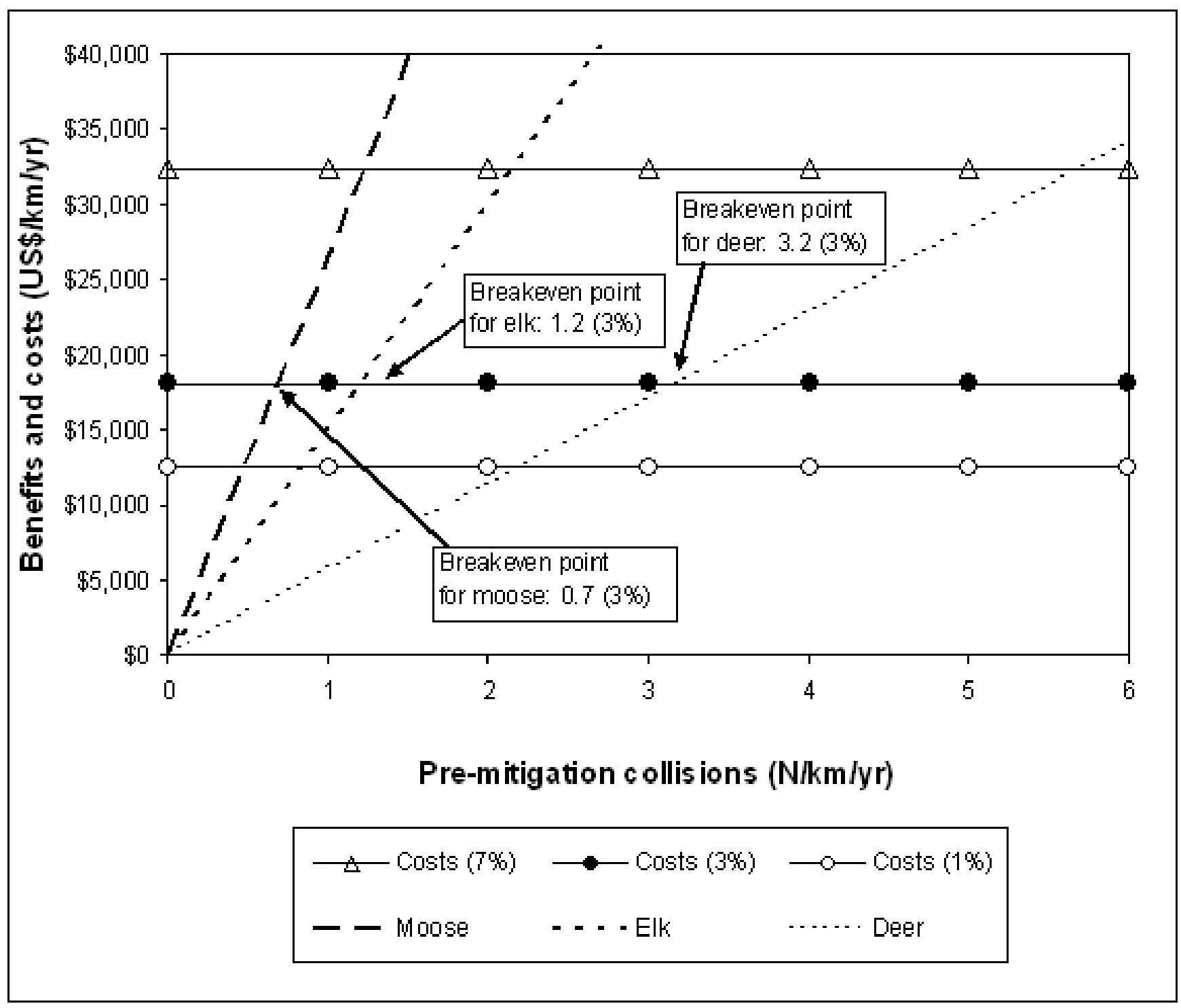

Another way to look at the same data is in terms of the actual "product" or output of the mitigation measures, which is the number of collisions avoided per kilometer per year (Fig. 7). From this perspective, the average benefits per collision avoided are constant (horizontal lines in Fig. 7) and depend on the species: deer US\$6617, elk US\$17 483, and moose US\$30 760 per kilometer per year.
Average costs per collision avoided, however, decline with the number of collisions avoided, illustrating the spreading of fixed costs that underlies the economics of these mitigation measures. The break-even point for deer, elk, and moose is at $2.7,1.0$, and 0.6 collisions avoided per kilometer per year, respectively (Fig. 7). If more collisions are avoided, then fencing with 
underpasses and jump-outs generates economic benefits in excess of costs. Similarly, if fewer collisions are avoided then this mitigation measure has costs in excess of benefits. Note that the breakeven values divided by the reduction achieved by the specific fencing with underpasses mitigation measure of 0.86 (or 86\%) yields the break-even point in terms of pre-mitigation collisions (Fig. 6).

\section{Threshold Values for the Mitigation Measures}

The minimum amount (in 2007 US\$) that a mitigation measure needs to generate in order to reach the break-even point increases with the discount rate (Tables 3 and 4). However, this value is not dependent on the discount rate for mitigation measures that require the same investment every year (i.e., for vegetation removal and anti-fertility treatment) (Table 3). These dollar-value thresholds were translated into break-even points for deer-, elk-, and moose-vehicle collisions per kilometer per year (Tables 3 and 4). If a road section has costs or wildlife-vehicle collision numbers that exceed these threshold values, then the benefits of that mitigation measure exceed the costs over a 75-year time period (measured in 2007 US\$). For example, if a road section averages 0.1 deer-vehicle collisions per kilometer per year, and if the collisions are concentrated in certain times of the year, a seasonal warning sign would be economically feasible (because the threshold value of $<0.1$ ( $3 \%$ discount rate) is exceeded), but this measure is only estimated to reduce collisions by $26 \%$ (see Table 1 ). If a road section averages 4.4 deer-vehicle collisions per kilometer per year, a combination of wildlife fencing, under- and overpasses, and jump-outs would be economically feasible (because the threshold value of 4.3 (3\% discount rate) is exceeded), and this measure is estimated to reduce collisions by $86 \%$ (see Table 1). Naturally, other mitigation measures that have threshold values lower than 4.4 deer per kilometer per year would also be economically feasible. Note that the threshold values presented in Tables 3 and 4 are based on a series of assumptions and estimates and that they should be taken as indicative values rather than exact values.

\section{Real-World Examples}

The costs associated with deer-, elk-, and moosevehicle collisions for 10 road sections in the United States and Canada varied between US\$3636 and US\$46 155 per kilometer per year (Table 5). Even though some of the road sections only have data for a relatively short period, and the search and reporting effort varies for the different road sections, the average costs are higher than the threshold values for some of the mitigation measures (see Tables 3 and 4), indicating that the benefits of implementing such mitigation measures over the full length of the road sections concerned exceed the costs, and that these measures would be economically feasible. When comparing the costs per kilometer per year to the threshold values in Tables 3 and 4, please note that these threshold values are based on a divided four-lane road, and that two-lane roads have lower threshold values for some of the mitigation measures (e.g., those that include under- or overpasses). A more detailed cost analysis for one of the road sections in Table 5, MT Hwy 83, showed that, even though the average costs per kilometer per year may not meet the thresholds of many of the mitigation measures, certain locations on a road section can still exceed these thresholds (Fig. 8). For example, the benefits of animal detection systems as a stand-alone mitigation measure exceed the costs on $4.2 \%$ of the $76.9 \mathrm{~km}$ (47.8 miles) road section. Similarly, this percentage is $9.4 \%$ for wildlife fencing with gaps and animal detection systems in these gaps and jump-outs: $16.3 \%$ for wildlife fencing with underand overpasses and jump-outs; and $26.8 \%$ for wildlife fencing with underpasses and jump-outs (Fig. 8).

\section{DISCUSSION}

The costs associated with deer-, elk-, and moosevehicle collisions are substantial. Most of the costs are associated with human injuries and fatalities (deer 56.0\%; elk 69.1\%; moose: $78.6 \%$ ) rather than vehicle repair costs (deer: 39.6\%; elk: 26.0\%; moose: $18.2 \%$ ). Of the approximately 40 different types of mitigation measures reviewed, only 13 were considered to be effective in reducing collisions with large ungulates. However, the degree of effectiveness and the costs of these 13 mitigation measures vary greatly and, consequently, there are substantial differences in the threshold values 
Fig. 7. The average costs per collision avoided per year for deer, elk, and moose for the mitigation measure fencing with underpasses (solid lines) (at 7\%, 3\%, and 1\% discount rate) and the costs associated with the average deer-, elk-, or moose-vehicle collision (dotted lines) (all in real 2007 US\$).

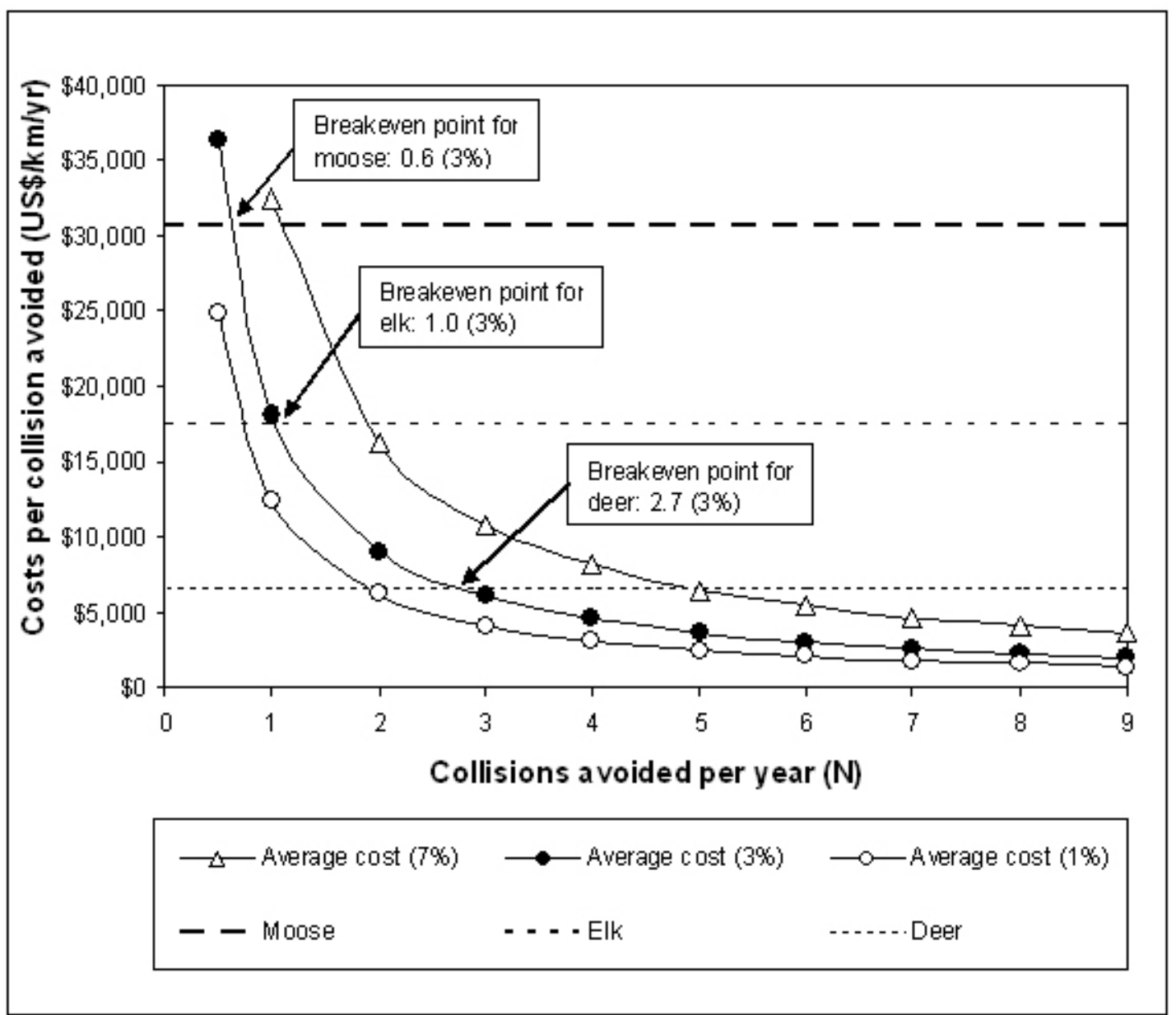

between the individual mitigation measures above which the benefits of a mitigation measure exceed the costs. Collision and carcass data from 10 road sections throughout the United States and Canada showed that some road sections easily meet the threshold values for some of the mitigation measures. This means that the benefits of implementing such mitigation measures over the full length of the road sections concerned exceed the costs and that the implementation of mitigation measures would be economically feasible. However, when calculating the average costs of wildlife-vehicle collisions over relatively long road sections, potential concentrations of wildlife- vehicle collisions are ignored. Therefore, it is important that more detailed analyses are carried out at a finer spatial scale (e.g., at $0.1-1.0 \mathrm{~km}$ or 0.1-1.0 mile resolution) to identify road sections where the benefits of mitigation measures may exceed the costs. Previous cost-benefit analyses estimated that wildlife fencing and wildlife fencing in combination with underpasses required 7.5 and 11.3 deer-vehicle collisions per kilometer per year, respectively, at a discount rate of $6 \%$ (Reed et al. 1982). These thresholds are higher than in our study, primarily because Reed et al. (1982) did not include the costs associated with human injuries and fatalities. 
Table 3. Threshold values for individual mitigation measures that are estimated to reduce collisions with large ungulates by $\leq 50 \%$ (see Table 1 for estimated percentages).

\begin{tabular}{|c|c|c|c|c|c|c|c|}
\hline Threshold values & $\begin{array}{l}\text { Disco- } \\
\text { unt } \\
\text { rate }\end{array}$ & $\begin{array}{l}\text { Seasonal } \\
\text { sign }\end{array}$ & $\begin{array}{l}\text { Vegetation } \\
\text { removal }\end{array}$ & $\begin{array}{l}\text { Fence, gap, } \\
\text { signs, } \\
\text { crosswalk, } \\
\text { jump-outs }\end{array}$ & $\begin{array}{l}\text { Population } \\
\text { culling }\end{array}$ & Relocation & $\begin{array}{l}\text { Anti-fertility } \\
\text { treatment }\end{array}$ \\
\hline $\mathrm{US} \$ / \mathrm{km} / \mathrm{yr}$ & $1 \%$ & $\$ 114$ & $\$ 530$ & $\$ 8153$ & $\$ 3040$ & $\$ 12652$ & $\$ 71110$ \\
\hline $\mathrm{US} \$ / \mathrm{km} / \mathrm{yr}$ & $3 \%$ & $\$ 121$ & $\$ 530$ & $\$ 10116$ & $\$ 3099$ & $\$ 12764$ & $\$ 71110$ \\
\hline $\mathrm{US} \$ / \mathrm{km} / \mathrm{yr}$ & $7 \%$ & $\$ 140$ & $\$ 530$ & $\$ 14972$ & $\$ 3215$ & $\$ 13164$ & $\$ 71110$ \\
\hline deer $/ \mathrm{km} / \mathrm{yr}$ & $1 \%$ & $<0.1$ & 0.2 & 3.1 & 0.9 & 3.8 & 21.5 \\
\hline deer $/ \mathrm{km} / \mathrm{yr}$ & $3 \%$ & $<0.1$ & 0.2 & 3.8 & 0.9 & 3.9 & 21.5 \\
\hline deer $/ \mathrm{km} / \mathrm{yr}$ & $7 \%$ & $<0.1$ & 0.2 & 5.7 & 1.0 & 4.0 & 21.5 \\
\hline $\mathrm{elk} / \mathrm{km} / \mathrm{yr}$ & $1 \%$ & $<0.1$ & $<0.1$ & 1.2 & 0.4 & 1.5 & 8.1 \\
\hline $\mathrm{elk} / \mathrm{km} / \mathrm{yr}$ & $3 \%$ & $<0.1$ & $<0.1$ & 1.5 & 0.4 & 1.5 & 8.1 \\
\hline $\mathrm{elk} / \mathrm{km} / \mathrm{yr}$ & $7 \%$ & $<0.1$ & $<0.1$ & 2.1 & 0.4 & 1.5 & 8.1 \\
\hline moose $/ \mathrm{km} / \mathrm{yr}$ & $1 \%$ & $<0.1$ & $<0.1$ & 0.7 & 0.2 & 0.8 & 4.6 \\
\hline moose $/ \mathrm{km} / \mathrm{yr}$ & $3 \%$ & $<0.1$ & $<0.1$ & 0.8 & 0.2 & 0.8 & 4.6 \\
\hline moose $/ \mathrm{km} / \mathrm{yr}$ & $7 \%$ & $<0.1$ & $<0.1$ & 1.2 & 0.2 & 0.9 & 4.6 \\
\hline
\end{tabular}

Although it may appear attractive to implement mitigation measures that have relatively low threshold values, not all mitigation measures reduce wildlife-vehicle collisions substantially. Therefore, whereas mitigation measures with relatively low threshold values and with limited effectiveness may be considered for road sections with relatively few wildlife-vehicle collisions, mitigation measures with higher threshold values and higher effectiveness may be considered for road sections that have relatively many wildlife-vehicle collisions.

Wildlife fencing as a stand-alone mitigation measure has relatively low threshold values and reduces wildlife-vehicle collisions substantially. However, we strongly advise against increasing the barrier effect of roads and traffic without providing for safe crossing opportunities at appropriate intervals (see, e.g., Bissonette and Adair 2008, Huijser et al. 2008). The reason wildlife fencing has relatively low thresholds is that connectivity for wildlife (a passive-use cost) was not included in our cost-benefit analyses. However, depending on the species and local population structure, connectivity across the landscape, including roads, can be critical for the long-term population viability of the species concerned, and perhaps especially for species that may not be frequently hit by cars and that have low population density in the area (e.g., Jaeger and Fahrig 2004). Future cost-benefit analyses may include a monetary value for having viable populations of different species, as well as other passive-use values. 
Table 4. Threshold values for individual mitigation measures that are estimated to reduce collisions with large ungulates by $\geq 80 \%$ (see Table 1 for estimated percentages).

\begin{tabular}{|c|c|c|c|c|c|c|c|c|}
\hline Threshold values & $\begin{array}{l}\text { Disc- } \\
\text { ount } \\
\text { rate }\end{array}$ & Fence & $\begin{array}{l}\text { Fence, } \\
\text { underpass, } \\
\text { jump-outs }\end{array}$ & $\begin{array}{l}\text { Fence, } \\
\text { under- and } \\
\text { overpass, } \\
\text { jump-outs }\end{array}$ & ADS & $\begin{array}{l}\text { Fence, gap, } \\
\text { ADS, jump- } \\
\text { outs }\end{array}$ & $\begin{array}{l}\text { Elevated } \\
\text { roadway }\end{array}$ & Road tunnel \\
\hline $\mathrm{US} \$ / \mathrm{km} / \mathrm{yr}$ & $1 \%$ & $\$ 5223$ & $\$ 12437$ & $\$ 15975$ & $\$ 35279$ & $\$ 25634$ & $\$ 2233094$ & $\$ 3328567$ \\
\hline $\mathrm{US} \$ / \mathrm{km} / \mathrm{yr}$ & $3 \%$ & $\$ 6304$ & $\$ 18123$ & $\$ 24230$ & $\$ 37014$ & $\$ 28150$ & $\$ 3109422$ & $\$ 4981333$ \\
\hline $\mathrm{US} \$ / \mathrm{km} / \mathrm{yr}$ & $7 \%$ & $\$ 8931$ & $\$ 32457$ & $\$ 45142$ & $\$ 41526$ & $\$ 34437$ & $\$ 5369961$ & $\$ 9246617$ \\
\hline deer $/ \mathrm{km} / \mathrm{yr}$ & $1 \%$ & 0.9 & 2.2 & 2.8 & 6.1 & 4.5 & 337.5 & 503.0 \\
\hline deer $/ \mathrm{km} / \mathrm{yr}$ & $3 \%$ & 1.1 & 3.2 & 4.3 & 6.4 & 4.9 & 470.0 & 752.8 \\
\hline deer $/ \mathrm{km} / \mathrm{yr}$ & $7 \%$ & 1.6 & 5.7 & 7.9 & 7.2 & 6.0 & 811.6 & 1397.4 \\
\hline $\mathrm{elk} / \mathrm{km} / \mathrm{yr}$ & $1 \%$ & 0.4 & 0.8 & 1.1 & 2.3 & 1.7 & 127.7 & 190.4 \\
\hline $\mathrm{elk} / \mathrm{km} / \mathrm{yr}$ & $3 \%$ & 0.4 & 1.2 & 1.6 & 2.4 & 1.9 & 177.9 & 284.9 \\
\hline $\mathrm{elk} / \mathrm{km} / \mathrm{yr}$ & $7 \%$ & 0.6 & 2.2 & 3.0 & 2.7 & 2.3 & 307.2 & 528.9 \\
\hline moose $/ \mathrm{km} / \mathrm{yr}$ & $1 \%$ & 0.2 & 0.5 & 0.6 & 1.3 & 1.0 & 72.6 & 108.2 \\
\hline moose $/ \mathrm{km} / \mathrm{yr}$ & $3 \%$ & 0.2 & 0.7 & 0.9 & 1.4 & 1.1 & 101.1 & 161.9 \\
\hline moose $/ \mathrm{km} / \mathrm{yr}$ & $7 \%$ & 0.3 & 1.2 & 1.7 & 1.6 & 1.3 & 174.6 & 300.6 \\
\hline
\end{tabular}

Wildlife fencing in combination with underpasses and jump-outs, or a combination of under- and overpasses and jump-outs, have thresholds low enough to be met at many road sections that have a concentration of collisions with large ungulates. Although the costs for an individual wildlife overpass is typically many times that for a wildlife underpass (estimated at 10 times higher costs, see Appendix 1), wildlife overpasses only increase the threshold values by $28.4 \%, 33.7 \%$ or $39.1 \%$ (at $1 \%$, $3 \%$, or $7 \%$ discount rate, respectively) when used sparingly in large-scale mitigation projects (in this case once every $24 \mathrm{~km}$, see Appendix 1).

Animal detection systems as a stand-alone mitigation measure, and wildlife fencing combined with both jump-outs and animal detection systems installed at gaps, have higher thresholds than wildlife fencing in combination with under- and overpasses and jump-outs, but they still are low enough to be met at many road sections that have a concentration of collisions with large ungulates. Nonetheless, although the data on the effectiveness of animal detection systems are encouraging, the estimate of the effectiveness of this mitigation measure are not nearly as robust as that for wildlife fencing in combination with under- and overpasses. Therefore, animal detection systems should still be considered experimental (see Huijser et al. (2006a) for a discussion on the relative strengths and weaknesses of animal detection systems and wildlife fencing in combination with under- and overpasses). 
Table 5. The cost of deer-, elk-, and moose-vehicle collisions for selected road sections in the USA and Canada (all in 2007 US\$). $\mathrm{R}=$ research project, $\mathrm{HM}=$ highway maintenance reports, $\mathrm{AR}=$ highway accident reports, $\mathrm{PWI}=$ park warden incident reports, $\mathrm{MSR}=$ meat salvage reports.

\begin{tabular}{|c|c|c|c|c|c|}
\hline Road section & Road length $(\mathrm{km})$ & $\begin{array}{l}\text { Data collection } \\
\text { and year }\end{array}$ & $\begin{array}{l}\text { Collisions } / \mathrm{km} / \mathrm{yr} \\
\text { (costs in } 2007 \\
\text { US\$) }\end{array}$ & $\begin{array}{l}\text { Total cost } / \mathrm{km} / \mathrm{yr} \\
\text { (US\$) }\end{array}$ & Source \\
\hline $\begin{array}{l}\text { SR260 (Christopher Creek section), } \\
\text { Payson, AZ, USA }\end{array}$ & 7.2 & $\begin{array}{l}\text { R, HM, AR } \\
(2002-2003)\end{array}$ & $\begin{array}{l}2.64 \text { elk }(\$ 46 \\
155)\end{array}$ & $\$ 46155$ & Dodd et al. 2007 \\
\hline $\begin{array}{l}\text { I-90 (309.0-330.9) (four-lane), } \\
\text { Bozeman Pass, MT, USA }\end{array}$ & 35.2 & R, HM (2003) & $\begin{array}{l}3.38 \text { deer }(\$ 22 \\
365) \\
0.21 \text { elk }(\$ 3671) \\
0.06 \text { moose } \\
(\$ 1845)\end{array}$ & $\$ 27881$ & Hardy et al. 2006 \\
\hline $\begin{array}{l}\text { I-80/90 (50.0-70.0), Indiana Toll Road } \\
\text { (four-lane), IN, USA }\end{array}$ & 32.2 & HM (2005) & $\begin{array}{l}2.89 \text { deer }(\$ 19 \\
123)\end{array}$ & $\$ 19123$ & $\begin{array}{l}\text { Sedat Gulen, } \\
\text { Indiana DOT, } \\
\text { pers. comm. }\end{array}$ \\
\hline $\begin{array}{l}\text { Alaska Hwy } 1 \text { (58.0-79.0) (two-lane), } \\
\text { AK, USA }\end{array}$ & 33.8 & AR, MSR (2006) & $\begin{array}{l}0.56 \text { moose }(\$ 17 \\
226)\end{array}$ & $\$ 17226$ & $\begin{array}{l}\text { Rick Ernst, Kenai } \\
\text { National Wildlife } \\
\text { Refuge, pers. } \\
\text { comm. }\end{array}$ \\
\hline $\begin{array}{l}\text { I-95 (near Medway) (four-lane), ME, } \\
\text { USA }\end{array}$ & 32.2 & AR (2005) & $\begin{array}{l}0.06 \text { deer }(\$ 397) \\
0.53 \text { moose }(16 \\
303)\end{array}$ & $\$ 16700$ & $\begin{array}{l}\text { Duane Brunell, } \\
\text { Maine DOT, pers. } \\
\text { comm. }\end{array}$ \\
\hline $\begin{array}{l}\text { Hwy 1, Banff National Park (Phase 3b) } \\
\text { (two-lane), AB, Canada }\end{array}$ & 28.1 & $\begin{array}{l}\text { AR, R, PWI } \\
(2005)\end{array}$ & $\begin{array}{l}0.60 \text { deer } \\
(\$ 3970) \\
0.32 \text { elk }(\$ 5595) \\
0.07 \text { moose } \\
(\$ 2153)\end{array}$ & $\$ 11718$ & $\begin{array}{l}\text { Shelagh Wrazej, } \\
\text { Parks Canada, } \\
\text { pers. comm. }\end{array}$ \\
\hline $\begin{array}{l}\text { Route } 169 \text { (1.0-61.0) (two-lane), } \\
\text { Laurentides Wildlife Reserve, QC, } \\
\text { Canada }\end{array}$ & 61.0 & HM, AR (2003) & $\begin{array}{l}0.33 \text { moose }(\$ 10 \\
151)\end{array}$ & $\$ 10151$ & $\begin{array}{l}\text { Yves Leblanc, } \\
\text { Tecsult Inc., pers. } \\
\text { comm. }\end{array}$ \\
\hline $\begin{array}{l}\text { I-90 (55.0-70.0) (four-lane), } \\
\text { Snoqualmie Pass, WA, USA }\end{array}$ & 24.1 & HM (2005) & $\begin{array}{l}0.70 \text { deer } \\
(\$ 4632) \\
0.25 \text { elk }(\$ 4371)\end{array}$ & $\$ 9003$ & $\begin{array}{l}\text { Victoria Fursman, } \\
\text { Washington DOT, } \\
\text { pers. comm. }\end{array}$ \\
\hline MT Hwy 83 (two-lane), MT, USA & 76.9 & HM (1998-2003) & $\begin{array}{l}1.19 \text { deer } \\
(\$ 7287) \\
0.01 \text { elk }(\$ 176)\end{array}$ & $\$ 7463$ & $\begin{array}{l}\text { Huijser et al. } \\
2006 b\end{array}$ \\
\hline $\begin{array}{l}\text { Highway } 93 \mathrm{~S} \text { (two-lane), Kootenay } \\
\text { National Park, BC, Canada }\end{array}$ & 34.2 & AR, PWI (2005) & $\begin{array}{l}0.41 \text { deer } \\
(\$ 2713) \\
0.03 \text { moose } \\
(\$ 923)\end{array}$ & $\$ 3636$ & $\begin{array}{l}\text { Shelagh Wrazej, } \\
\text { Parks Canada, } \\
\text { pers. comm. }\end{array}$ \\
\hline
\end{tabular}


Fig. 8. The costs (in 2007 US\$) associated with wildlife-vehicle collisions (deer and elk) along the twolane MT Hwy 83 (mile reference posts 0.0-47.8) per year (average 1998-2003), and the threshold values (at $3 \%$ discount rate) that need to be met in order to have the benefits of individual mitigation measures exceed the costs over a 75-year time period. Note that the costs at each 0.1 mile concerned and five adjacent 0.1 mile units were summed $(0.6$ mile $=1 \mathrm{~km})$ to estimate the costs per kilometer.

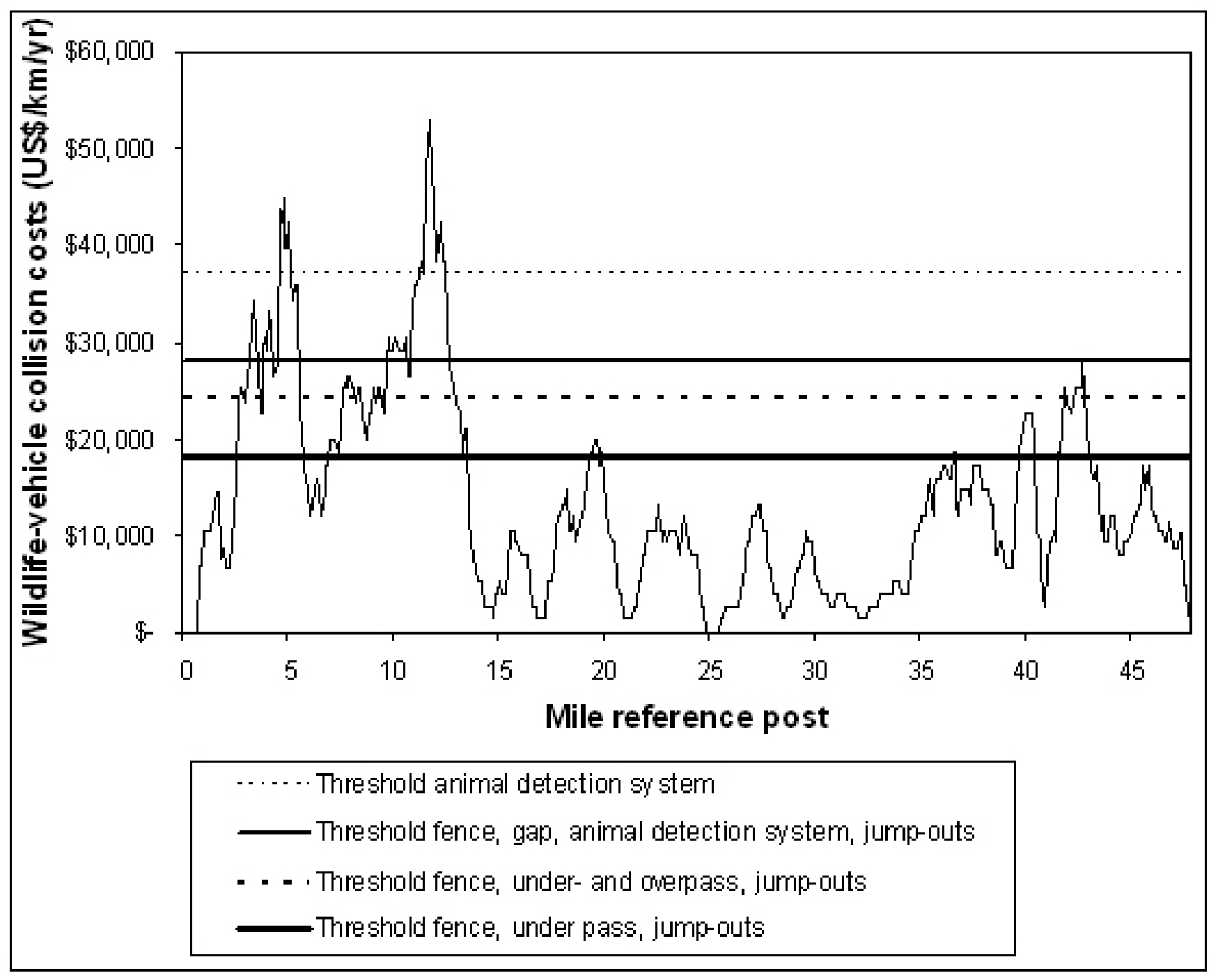

Elevated roadways and road tunnels have very high threshold values, suggesting that these measures are unlikely to be implemented based on an economic analysis of deer-, elk-, or moose-vehicle collisions alone. Elevated roadways or road tunnels appear to be put in place primarily because of landscape characteristics (e.g., the presence of a mountain or a canyon), ecosystem processes (e.g., the flow of large amounts of water in rivers), and perhaps concerns for specific threatened or endangered species (e.g., Evink 2002, Huijser et al. 2007b). This also illustrates another limitation of our cost-benefit analyses; it is primarily focused on the costs and benefits of collisions with large ungulates and the impacts on human safety. If other parameters are included it may change the threshold values substantially. 
The threshold values for the individual mitigation measures are based on the mitigation of relatively long road sections (e.g., at least several kilometers or miles). This is especially important for the mitigation measures that include safe crossing opportunities (one safe crossing opportunity per 2 $\mathrm{km}$, see Appendix 1). In this context, it is also critical to consider the habitat and home range of the species concerned to prevent individual animals from simply walking to the beginning or end of a mitigated road section to cross the road there, potentially reducing the effectiveness of the mitigation measure (see, e.g., Huijser et al. 2008).

The costs associated with collisions with large ungulates are a current estimate and may be subject to change when additional studies are conducted. The same is true for the costs (e.g., price of fuel, concrete, and steel) and effectiveness of the individual mitigation measures. In addition, mass production, the use of less expensive materials and construction techniques, and incorporating mitigation measures early in the planning of road (re-) construction projects may further reduce the costs for mitigation measures. Furthermore, there may be biases in our estimates for the costs of collisions with large ungulates. For example, the cost estimates for deer-, elk-, and moose-vehicle collisions only relate to the collisions reported to the insurance industry or to law enforcement agencies, and one could argue that unreported collisions are likely to be less costly than reported collisions. Therefore, we may have overestimated the average costs of a collision with a deer, elk, or moose. On the other hand, insurance industry reports and police accident reports may underestimate ungulate-vehicle collisions by about 50\% (Tardif and Associates Inc. 2003, Riley and Marcoux 2006), and law enforcement agencies may only record a fraction (14\%) of the deer-vehicle collisions reported to the insurance industry (Donaldson and Lafon 2008). Furthermore, in most states and provinces in the United States and Canada, no accident report is filled out by law enforcement agencies if the estimated vehicle damage is less than US $\$ 1000$ (Huijser et al. 2007b). The most conservative approach would be to only include collisions that were reported to the insurance industry or law enforcement agencies and screen the data for potential duplicates. However, based on the studies cited above, it is clear that such an approach may lead to a serious underestimation of the actual costs of collisions with large ungulates, and one may choose to include carcass reports, recognizing that although this may overestimate the average costs associated with a deer-, elk--, or moose-vehicle collision, it may still underestimate the actual number of ungulate-vehicle collisions by about $50 \%$. Crash and carcass data collection can be much improved (see also Huijser 2007b), which would greatly benefit the accuracy of cost-benefit analyses that evaluate the economic feasibility of mitigation measures.

\section{CONCLUSION}

We believe that the cost-benefit model presented in this paper can be a valuable decision-support tool for transportation agencies and natural resource management agencies when deciding on the implementation of mitigation measures to reduce ungulate-vehicle collisions. The tool allows for the selection of the appropriate road sections as well as the type of mitigation measure. The results suggest that there must be many road sections in the United States and Canada where the benefits of mitigation measures exceed the costs and where the mitigation measures would help society save money and improve road safety for humans and wildlife. Mitigation measures that include safe crossing opportunities for wildlife may not only substantially reduce road mortality, but also allow for wildlife movements across the road. This connectivity is essential to the survival probability of the fragmented populations for some species in some regions.

Responses to this article can be read online at: http://www.ecologyandsociety.org/voll4/iss2/art15/ responses/

\section{Acknowledgments:}

This effort was funded, in part, by the Wilburforce Foundation. The authors would like to thank the Wilburforce Foundation for their support. In addition, the authors also thank Pat Basting, Duane Brunell, Rick Ernst, Jon Fleming, Victoria Fursman, Yves Leblanc, Dick Luedke, Terry McGuire, Sedat Gulen, Doug Herbrand, Chris Neher, Lloyd Salsman, Rodney van der Ree, Bethanie Walder, Shelagh Wrazej, and three anonymous reviewers for their help, comments, and suggestions. 


\section{LITERATURE CITED}

Allen, R. E., and D. R. McCullough. 1976. Deercar accidents in southern Michigan. Journal of Wildlife Management 40:317-325.

Ament, R., A. P. Clevenger, O. Yu, and A. Hardy. 2008. An assessment of road impacts on wildlife populations in US National Parks. Environmental Management 42(3):480-496.

Andreassen, H.P., H. Gundersen, and T. Storaas. 2005. The effect of scent-marking, forest clearing, and supplemental feeding on moose-train collisions. Journal of Wildlife Management 69 (3):1125-1132.

Beringer, J., L. P. Hansen, J. A. Demand, J. Sartwell, M. Wallendorf, and R. Mange. 2002. Efficacy of translocation to control urban deer in Missouri: costs, efficiency, and outcome. Wildlife Society Bulletin 30(3):767-774.

Bissonette, J. A., and W. Adair. 2008. Restoring habitat permeability to roaded landscapes with isometrically-scaled wildlife crossings. Biological Conservation 141(2):482-488.

Bissonette, J. A., and M. Hammer. 2000. Effectiveness of earthen ramps in reducing big game highway mortality in Utah. Final Report. USGS Utah cooperative Fish and Wildlife Research Unit, Utah State University, Logan, Utah, USA.

Bissonette, J. A., C. A. Kassar, and L. J. Cook. 2008. Assessment of costs associated with deervehicle collisions: human death and injury, vehicle damage, and deer loss. Human-Wildlife Conflicts 2 (1):17-27.

Clayton Resources Ltd. and Glen Smith Wildlife Consultants. 1989. Wildlife fencing and control on the Okanagan connector highway: a benefit cost analysis. Clayton Resources Ltd., Victoria, British Columbia, Canada.

Clevenger, A. P., B. Chruszcz, and K. Gunson. 2001. Highway mitigation fencing reduces wildlife-vehicle collisions. Wildlife Society Bulletin 29:646-653.

Clevenger, A. P., B. Chruszcz, K. Gunson, and J. Wierzchowski. 2002. Roads and wildlife in the Canadian Rocky Mountain Parks: movements, mortality and mitigation. Final report to Parks Canada. Banff, Alberta, Canada.

Conn, J. M., J. L. Annest, and A. Dellinger. 2004. Nonfatal motor-vehicle animal crash-related injuries-United States, 2001-2002. Journal of Safety Research 35:571- 574.

Conover, M. R. 1997. Monetary and intangible valuation of deer in the United States. Wildlife Society Bulletin 25:298-305.

Conover, M. R., W. C. Pitt, K. K. Kessler, T. J. DuBow, and W. A. Sanborn. 1995. Review of human injuries, illnesses, and economic losses caused by wildlife in the United States. Wildlife Society Bulletin 23:407-414.

Crête, M., and C. Daigle. 1999. Management of indigenous North American deer at the end of the $20^{\text {th }}$ century in relation to large predators and primary productivity. Acta Veterinaria Hungarica 47:1-16.

Daily, G. C., S. Alexander, P. R. Ehrlich, L. Goulder, J. Lubchenco, P. A. Matson, H. A. Mooney, S. Postel, S. H. Schneider, D. Tilman, and G. M. Woodwell. 1997. Ecosystem services: benefits supplied to human societies by natural ecosystems. Issues in Ecology 2:1-16.

DeNicola, A. J., K. C. VerCauteren, P. D. Curtis, and S. E. Hygnstrom. 2000. Managing whitetailed deer in suburban environments: a technical guide. Cornell Cooperative Extension, The Wildlife Society-Wildlife Damage Management Working Group, and the Northeast Wildlife Damage Research and Outreach Cooperative, Ithaca, New York, USA.

Dodd, N., and J. Gagnon. 2008. Preacher Canyon Wildlife Fence and Crosswalk Enhancement Project State Route 260, Arizona. First year progress report. Project JPA 04-088. Arizona Game and Fish Department, Research Branch, Phoenix, Arizona, USA.

Dodd, N. L., J. W. Gagnon, S. Boe, A. Manzo, and R. E.Schweinsburg. 2007. Evaluation of measures to minimize wildlife-vehicle collisions and maintain permeability across highways: Arizona Route 260. Final Report 540. FHWA-AZ-07-540. Arizona Department of Transportation, Phoenix, Arizona, USA. 
Doerr, M. L., J. B. McAninch, and E. P. Wiggers. 2001. Comparison of four methods to reduce whitetailed deer abundance in an urban community. Wildlife Society Bulletin 29(4):1105-1113.

Donaldson, B. M., and N. W. Lafon. 2008. Testing an integrated PDA-GPS system to collect standardized animal carcass removal data. FHWA/ VTRC 08-CR10. Virginia Transportation Research Council, Charlottesville, Virginia, USA.

Evink, G. L. 2002. Interaction between roadways and wildlife ecology. NCHRP Synthesis 305. Transportation Research Board, Washington, D.C., USA.

Foster, M. L., and S. R. Humphrey. 1995. Use of highway underpasses by Florida panthers and other wildlife. Wildlife Society Bulletin 23(1):95-100.

Garrett, L. C., and G. A. Conway. 1999. Characteristics of moose-vehicle collisions in Anchorage, Alaska, 1991-1995. Journal of Safety Research 30:219-223.

Government of Newfoundland and Labrador. 1997. Results of review of moose-vehicle collisions. News release 11 July 1997. [online] URL: http://w ww.gov.nf.ca/releases/1997/forest/0711n02.htm.

Grund, M.D., J. B. McAninch, and E.P. Wiggers. 2002. Seasonal movements and habitat use of female white-tailed deer associated with an urban park. Journal of Wildlife Management $\mathbf{6 6}$ (1):123-130.

Gryz, J., and D. Krauze. 2008. Mortality of vertebrates on a road crossing the Biebrza Valley (NE Poland). European Journal of Wildlife Research 54(4):709-714.

Hardy, A. R., J. Fuller, S. Lee, L. Stanley, and A. Al-Kaisy. 2006. Bozeman Pass wildlife channelization ITS project. Final report to Montana Department of Transportation. Western Transportation Institute Montana State University, Bozeman, Montana, USA.

Hedlund, J. H., P. D. Curtis, G. Curtis, and A. F. Williams. 2004. Methods to reduce traffic crashes involving deer: what works and what does not. Traffic Injury Prevention 5:122-131.

Hobday, A. J., and M. L. Minstrell. 2008.
Distribution and abundance of roadkill on Tasmanian highways: human management options. Wildlife Research 35(7):712-726.

Holsbeek, L., J. Rodts, and S. Muyldermans. 1999. Hedgehog and other animal traffic victims in Belgium: results of a countrywide survey. Lutra 42 (1):111-119.

Huijser, M. P., and P. J. M. Bergers. 2000. The effect of roads and traffic on hedgehog (Erinaceus europaeus) populations. Biological Conservation 95:111-116.

Huijser, M. P., J. Fuller, M. E. Wagner, A. Hardy, and A. P. Clevenger. 2007a. Animal-vehicle collision data collection. A synthesis of highway practice. NCHRP Synthesis 370. Project 20-05/ Topic 37-12. Transportation Research Board of the National Academies, Washington, D.C., USA.

Huijser, M. P., K. E. Gunson, and C. Abrams. 2006a. Animal-vehicle collisions and habitat connectivity along US Highway 83 in the SeeleySwan Valley: a reconnaissance. Report no. FHWA/ MT-06-002/8177. Western Transportation Institute Montana State University, Bozeman, Montana, USA.

Huijser, M. P., P. T. McGowen, W. Camel, A. Hardy, P. Wright, A. P. Clevenger, L. Salsman, and T. Wilson. 2006b. Animal vehicle crash mitigation using advanced technology. Phase I: review, design and implementation. SPR 3(076). FHWA-OR-TPF-07-01, Western Transportation Institute - Montana State University, Bozeman, Montana, USA.

Huijser, M. P., P. McGowen, J. Fuller, A. Hardy, A. Kociolek, A. P. Clevenger, D. Smith, and R. Ament. 2007b. Wildlife-vehicle collision reduction study. Report to Congress. U.S. Department of Transportation, Federal Highway Administration, Washington D.C., USA.

Huijser, M. P., K. J. S. Paul, L. Oechsli, R. Ament, A. P. Clevenger, and A. Ford. 2008. Wildlifevehicle collision and crossing mitigation plan for Hwy 93 S in Kootenay and Banff National Park and the roads in and around Radium Hot Springs. Report 4W1929 B, Western Transportation Institute Montana State University, Bozeman, Montana, USA. 
Jaeger, J. A. G., and L. Fahrig. 2004. Effects of road fencing on population persistence. Conservation Biology 18(6):1651-1657.

Jaren, V., R. Andersen, M. Ulleberg, P. H. Pedersen, and B. Wiseth. 1991. Moose-train collisions: the effects of vegetation removal with a cost-benefit analysis. Alces 27:93-99.

Joyce, T. L., and S. P. Mahoney. 2001. Spatial and temporal distributions of moose vehicle collisions in Newfoundland. Wildlife Society Bulletin 29 (1):281-291.

Kilpatrick, H. J., and S. M. Spohr. 2000. Movements of female white-tailed deer in a suburban landscape: A management perspective. Wildlife Society Bulletin 28(4):1038-1045.

Kilpatrick, H. J., S. M. Spohr, and K. K. Lima. 2001. Effects of population reduction on home ranges of female white-tailed deer at high densities. Canadian Journal of Zoology 79(6):949-954.

Knapp, K., X. Yi, T. Oakasa, W. Thimm, E. Hudson, and C. Rathmann. 2004. Deer-vehicle crash countermeasure toolbox: a decision and choice resource. Final report. Report Number DVCIC - 02. Midwest Regional University Transportation Center, Deer-Vehicle Crash Information Clearinghouse, University of WisconsinMadison, Madison, Wisconsin, USA.

Knapp K. K., and A. Witte. 2006. Strategic agenda for reducing deer-vehicle crashes. Report No. DVCIC - 04. Midwest Regional University Transportation Center, Deer-Vehicle Crash Information Clearinghouse, University of Wisconsin, Madison, WI, USA.

Kratky, J. 1995. Vertebrate casualties on the roads of the Middle Elbe lowlands. Casopis Narodniho Muzea Rada Prirodovedna 164(1-4):91-97.

Kruidering, A. M., G. Veenbaas, R. Kleijberg, G. Koot, Y. Rosloot, and E. van Jaarsveld. 2005. Leidraad faunavoorzieningen bij wegen. Rijkswaterstaat, Dienst Weg-en Waterbouwkunde, Delft, The Netherlands.

Krutilla, J. V. 1967. Conservation reconsidered. American Economic Review 57:777-786.

Lavsund, S., and F. Sandegren. 1991. Moose- vehicle relations in Sweden: a review. Alces 27:118-126.

Lehnert, M. E., and J. A. Bissonette. 1997. Effectiveness of highway crosswalk structures at reducing deer vehicle collisions. Wildlife Society Bulletin 25(4):809-818.

Mansergh I. M., and D. J. Scotts. 1989. Habitat continuity and social organisation of the mountain pygmy-possum restored by tunnel. Journal of Wildlife Management 53:701-707.

Mosler-Berger, C., and J. Romer. 2003. Wildwarnsystem CALSTROM. Wildbiologie 3:112.

Porter, W. F., and H. B. Underwood. 1999. Of elephants and blind men: deer management in the US National Parks. Ecological Applications 9(1):39.

Proctor, M. F. 2003. Genetic analysis of movement, dispersal and population fragmentation of grizzly bears in southwestern Canada. Dissertation. The University of Calgary, Calgary, Alberta, Canada.

Provincie Noord-Brabant. 2004. Ecoduct over de A2. Provincie Noord-Brabant, Den Bosch, The Netherlands.

Rattey, T. E., and N. E. Turner. 1991. Vehiclemoose accidents in Newfoundland. The Journal of Bone and Joint Surgery 73(10):1487-1491.

Reed, D. F., T. D. I. Beck, and T. N. Woodward. 1982. Methods of reducing deer-vehicle accidents: benefit-cost analysis. Wildlife Society Bulletin 10:349-354.

Reeve, A. F., and S. H. Anderson. 1993. Ineffectiveness of Swareflex reflectors at reducing deer-vehicle collisions. Wildlife Society Bulletin 21:127-132.

Riley, S. J., and A. Marcoux. 2006. Deer-vehicle collisions: an understanding of accident characteristics and drivers' attitudes, awareness and involvement. Research report RC-1475. Department of Fisheries and Wildlife, Michigan State University, East Lansing, Michigan, USA.

Rogers, E. 2004. An ecological landscape study of deer vehicle collisions in Kent County, Michigan. 
Report by White Water Associates Inc. Prepared for Kent County Road Commission, Grand Rapids, Michigan, USA.

Romin, L. A., and J. A. Bissonette. 1996. Deervehicle collisions: status of state monitoring activities and mitigation efforts. Wildlife Society Bulletin 24:276-283.

Rudolph, B. A., W. F. Porter, and H. B. Underwood. 2000. Evaluating immunocontraception for managing suburban white-tailed deer in Irondequoit, New York. Journal of Wildlife Management 64(2):463-473.

Schwabe, K. A., P. W. Schuhmann, M. J. Tonkovich, and E. Wu. 2002. An analysis of deervehicle collisions: the case of Ohio. Pages: 91-103 in L. Clark, editor. Human conflicts with wildlife: economic considerations. National Wildlife Research Center, Fort Collins, Colorado, USA.

Seagle, S. W., and J. D. Close. 1996. Modeling white-tailed deer (Odocoileus virginianus) population control by contraception. Biological Conservation 76(1):87-91.

Seibert, H. C., and J. H. Conover. 1991. Mortality of vertebrates and invertebrates on an Athens County, Ohio, USA highway. Ohio Journal of Science Volume 91(4):163-166.

Seiler, A. 2003. The toll of the automobile: wildlife and roads in Sweden. Dissertation, Swedish University of Agricultural Sciences, Uppsala, Sweden.

Sielecki, L. E. 2004. WARS 1983-2002. Wildlife accident reporting and mitigation in British Columbia: special annual report. Ministry of Transportation, Engineering Branch, Environmental Management Section, Victoria, British Columbia, Canada.

Southeast Michigan Council of Governments (SEMCOG). 2007. Michigan Deer crash coalition. [online] URL: http://www.semcog.org/MDCC.aspx

Sullivan, T. L., A. E. Williams, T. A. Messmer, L. A. Hellinga, and S. Y. Kyrychenko. 2004. Effectiveness of temporary warning signs in reducing deer vehicle collisions during mule deer migrations. Wildlife Society Bulletin 32(3):907915.
Sumaila, U. R., and C. Walters. 2005. Intergenerational discounting: a new intuitive approach. Ecological Economics 52:135-142.

Tardif, L. -P., and Associates Inc. 2003. Collisions involving motor vehicles and large animals in Canada. Final report. L-P Tardif and Associates Inc., Nepean, Ontario, Canada.

Thomas, E. 1995. Moose-vehicle accidents on Alaska's rural highways. State of Alaska, Department of Transportation and Public Facilities, Central Region, Design and Construction Division, Fairbanks, Alaska, USA.

Ujvári, M., H. J. Baagøe, and A. B. Madsen. 1998. Effectiveness of wildlife warning reflectors in reducing deer-vehicle collisions: a behavioural study. Journal of Wildlife Management 62:10941099.

USA Traffic Signs. 2007. Warning for deer crossing sign. USA Traffic Signs, Binghamton, New York, USA. [online] URL: http://www.usa-traffic-signs.com/

U.S. Department of Labor. 2008. Consumer Price Index. Bureau of Labor Statistics, Washington, D. C., USA. [online] URL: ftp://ftp.bls.gov/pub/special. requests/cpi/cpiai.txt.

U.S. Department of Transportation. 1994. Technical advisory. Motor vehicle accident costs. T 7570.2 October 31, 1994. U.S. Department of Transportation, Federal Highway Administration, Washington, D.C., USA.

U.S. Environmental Protection Agency. 2000. Guidelines for economic analysis. EPA 240R-00-003. [online] URL: http://yosemite.epa.gov/ee/ epa/eed.nsf/webpages/Guidelines.html.

U.S. Fish and Wildlife Service. 1998. Net economic values for bass, trout, and walleye fishing, deer, elk, and moose hunting, and wildlife watching. [online] URL: http://wsfrprograms.fws.gov/Subpages/ NationalSurvey/National Survey.htm.

U.S. Fish and Wildlife Service. 2002. 50 state reports, 2001 national survey offishing, hunting and wildlife-associated recreation. [online] URL: http:/ /wsfrprograms.fws.gov/Subpages/NationalSurvey/ National Survey.htm. 
U.S. Fish and Wildlife Service. 2003. Net economic values for wildlife-related recreation in 2001: Addendum to the 2001 national survey of fishing, hunting, and wildlife-associated recreation. [online] URL: http://wsfrprograms.fws.gov/Subpages/ NationalSurvey/National Survey.htm.

U.S. Office of Management and Budget. 1992. Circular A-94. Guidelines and discount rates for benefit-cost analysis of federal programs. [online] URL: http://www.whitehouse.gov/omb/assets/omb/ circulars/a094/aO94.pdf.

van der Ree R., M. A. McCarthy, D. Heinze, and I. M. Mansergh. 2009. Under-road tunnel restores population dynamics of endangered pygmypossum. Ecology and Society 14, in press.

van der Zee, F. F., J. Wiertz, C. J .F. ter Braak, R. C. van Apeldoorn, and J. Vink. 1992. Landscape change as a possible cause of the badger Meles meles L. decline in The Netherlands. Biological Conservation 61:17-22.

Walter, W. D., P. J. Perkins, A. T. Rutberg, and H. J. Kilpatrick. 2002. Evaluation of immunocontraception in a free-ranging suburban white-tailed deer herd. Wildlife Society Bulletin 30(1):186-192.

Ward, A. L. 1982. Mule deer behavior in relation to fencing and underpasses on Interstate 80 in Wyoming. Transportation Research Record 859:813.

Ward, K. M., and J. W. Duffield. 1992. Natural resource damages: law and economics. Wiley, New York, New York, USA.

Weitzman, M. L. 2001. Gamma discounting. American Economic Review 91(1):260-271.

Williams, A. F., and J. K. Wells. 2005. Characteristics of vehicle-animal crashes in which vehicle occupants are killed. Traffic Injury Prevention 6:56-59.

Woods, J. G. 1990. Effectiveness of fences and underpasses on the Trans-Canada highway and their impact on ungulate populations. Report to Banff National Park Warden Service, Banff, Alberta, Canada. 


\section{Appendix 1. Cost Estimates for Mitigation Measures}

\section{Please click here to download file 'appendixl.pdf'.}


Appendix 2. Cost Estimates for Deer-, Elk-, and Moose-Vehicle Collisions

Please click here to download file 'appendix2.pdf'. 